\title{
Tomasz Czakon
}

Uniwersytet Śląski w Katowicach

(iD https://orcid.org/0000-0001-5697-3651

\section{Deklarowany etos nauki polskich uczelni}

\section{The Declared Scientific Ethos of Polish Universities}

\begin{abstract}
The principles that govern the functioning of science and visions of the ethics of scientific research are changing. Many researchers who are examining these changes observe a shift from the academic ethos to the industrial — or "corporate" - ethos. Under the new law on higher education and science, which was passed by the Polish Parliament in 2018, new regulations to the Polish state university system have come into effect. The basic aim of my article has been to examine the scientific ethos in Poland. I based my research on the new statutes adopted by university senates, in which I focused on the value statements and declarations that express the beliefs of university authorities about the most important and desirable model of science. I compared two groups of universities, those which have obtained the status of research universities and colleges from the Upper Silesian Metropolis. My goal was to answer the following questions: 1 . What values create the declared ethos of science? 2. What is their hierarchy? 3. To what extent is the ethos of both groups of universities similar? 4. Has the scientific ethos present in the new statutes changed in relation to what was declared earlier? In order to answer these questions, I have applied the technique of document content analysis. My research shows that 1 . The ethos of science is changing; 2. The set of declared values in the material under scrutiny is rich and varied.
\end{abstract}

Keywords: ethos, scientific ethos, university 


\section{Wstęp}

W artykule przedstawiam deklarowany ${ }^{1}$ etos nauki zapisany w przyjętych przez senaty publicznych wyższych uczelni statutach po uchwaleniu w lipcu 2018 roku nowej ustawy o szkolnictwie wyższym i nauce ${ }^{2}$. O ile przemiany postaw badaczy wobec sposobu pojmowania nauki są przedmiotem zainteresowania ${ }^{3}$, nie ma badań analizy treści podstawowych dokumentów uczelni wyższych pod kątem obecności wartości tworzących etos nauki. Aby wypełnić tę lukę, postanowiłem przeanalizować owe dokumenty (to znaczy statuty, strategie rozwoju, misje uczelni) przyjęte przez senaty wyższych uczelni publicznych po wejściu w życie nowej ustawy. Zamiar udało się zrealizować częściowo, ponieważ do czasu podjęcia tego badania ${ }^{4}$ większość uczelni przyjęła tylko nowe statuty; nie zostały ogłoszone strategie rozwoju, misje uczelni. Tylko jeden $\mathrm{z}$ uniwersytetów będących przedmiotem zainteresowania przyjął $\mathrm{w}$ tym czasie także nową strategię rozwoju, która została uwzględniona $\mathrm{w}$ analizie. W dokumentach tych, oprócz oczywiście dominujących w nich rozstrzygnięć o charakterze organizacyjnym, znalazły się również liczne deklaracje o charakterze bardziej ogólnym, a także aksjologicznym. Znajdują się one najczęściej w odrębnych, początkowych częściach dokumentów. Właśnie tego typu deklaracje czynię przedmiotem swoich badań. Interesuje mnie, jakie wartości konstruujące deklarowany etos nauki zapisano $\mathrm{w}$ analizowanych dokumentach uczelni wyższych - nie interesują mnie reguły, które (przykładowo) określają sposób organizacji zajęć, natomiast biorę pod uwagę deklaracje, że dla uczelni sprawa dydaktyki, wychowania jest ważna. Oczywiście punktem odniesienia zapisów w statutach uczelni jest ustawa zakładająca określony etos nauki, jednak $\mathrm{w}$ dokumentach przyjmowanych przez senaty uczelni w odmienny sposób ujmuje się te zasady, i to jest ważne. Za istotny uznałem sposób odzwierciedlania się tego samego impulsu w etosach różnych grup naukowców.

${ }^{1}$ Deklarowany etos nauki, co chcę podkreślić, jest bardziej wzniosły od faktycznie realizowanego, uzasadnienie tej tezy wymaga jednak odrębnego tekstu.

2 Ustawa z dnia 20 lipca 2018 r. - Prawo o szkolnictwie wyższym i nauce. „Dziennik Ustaw" 2018, poz. 1668.

${ }^{3} \mathrm{O}$ etosie naukowców w Polsce, jego zróżnicowaniu piszą: M. Feldy: Etos nauki a podejście do promocji nauki. „MINIB. Marketing Instytucji Naukowych i Badawczych” 2018, nr 2 (28), s. 67-98. https://doi.org/10.14611/minib.28.06.2018.04; J. BIELIŃSKI, A. Tomczyńska: Etos nauki we współczesnej Polsce. „Nauka i Szkolnictwo Wyższe” 2019, nr 1-2 (53-54), s. 219—250. https://doi.org/10.14746//nisw.2019.1-2.7.

${ }^{4}$ Początek prac przypadł na wiosnę 2020 roku. 
Przedmiotem badania są statuty dwóch grup uczelni: tych, które uzyskały status uczelni badawczych, oraz — dla porównania - tych, które znajdują się na obszarze Górnośląsko-Zagłębiowskiej Metropolii. Zakładam, że uczelnie badawcze nie tylko są formalnymi liderami, lecz także wyznaczają sposób pojmowania etosu nauki. Aby sprawdzić, czy moje przypuszczenie jest trafne, badam również dokumenty uczelni publicznych z drugiej grupy mających swoje siedziby na terenie GZM. Biorę pod uwagę uczelnie $z$ tej grupy, ponieważ ich kodeksy etyczne i inne dokumenty, w których obecne są etyczne wątki, zostały już przeze mnie przeanalizowane pod kątem etosu nauki ${ }^{5}$, dzięki temu będę mógł porównać nie tylko etosy nauki uczelni badawczych i pozostałych, lecz także dostrzec ewentualne zmiany w statutach górnośląskich uczelni wywołane przyjęciem nowej ustawy o szkolnictwie wyższym i nauce.

Grupę uczelni badawczych tworzą te, które zostały wyłonione w rezultacie przeprowadzenia pierwszego konkursu „Inicjatywa doskonałości -

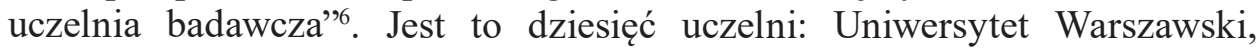
Politechnika Gdańska, Akademia Górniczo-Hutnicza im. Stanisława Staszica w Krakowie, Politechnika Warszawska, Uniwersytet im. Adama Mickiewicza w Poznaniu, Uniwersytet Jagielloński w Krakowie, Gdański Uniwersytet Medyczny, Politechnika Śląska w Gliwicach, Uniwersytet Mikołaja Kopernika w Toruniu, Uniwersytet Wrocławski. Uczelniami z grupy porównawczej są: Uniwersytet Śląski w Katowicach, Politechnika Śląska w Gliwicach, Śląski Uniwersytet Medyczny w Katowicach, Uniwersytet Ekonomiczny w Katowicach. Jedyną uczelnią, która znalazła się w obu grupach, jest Politechnika Śląska w Gliwicach.

Interesuje mnie uzyskanie odpowiedzi na kilka pytań:

1. Jakie wartości, normy, deklaracje tworzą deklarowany etos nauki?

2. Czy, a jeśli tak, to w jakim stopniu te deklaracje mieszczą się etosie nauki akademickiej?

3. W jakim stopniu etosy obu grup uczelni są podobne?

4. Czy etos nauki zapisany w nowych statutach uległ zmianie w stosunku do tego, co deklarowały uczelnie wcześniej?

W swoich analizach wziąłem pod uwagę dyskusje dotyczące przekształceń w nauce, szczególnie zarzuty, że nauka jest coraz bardziej skomercjalizowana, a uczelnie coraz bardziej przypominają „korporacje”. Przypusz-

5 T. Czakon: Etos nauki naukowców a etos nauki w kodeksach etycznych wyższych uczelni. „Analecta. Studia i Materiały z Dziejów Nauki” 2018, R. 27, z. 2 (53), s. 99-113.

${ }^{6}$ [Lista uczelni wyłonionych w pierwszym konkursie programu Ministra Nauki i Szkolnictwa Wyższego „Inicjatywa doskonałości - uczelnia badawcza”]. http://www.bip.nauka.gov.pl/g2/oryginal/2019_10/6ce53b5cae3f256eb8095549c7fa71c4.pdf [dostęp: 18.04.2020]. 
czam - i taka jest jedna $\mathrm{z}$ moich hipotez — że w etosie nauki zapisanym w nowych dokumentach uczelni wyższych znajdzie się zestaw wartości, który zaliczany jest do etosu postakademickiego, a nawet przemysłowego. $\mathrm{Z}$ tą hipotezą wiąże się kolejna: przyjęcie nowej ustawy o szkolnictwie wyższym i nauce znacząco wpływa na zmianę etosu nauki.

Do badania dokumentów, głównie statutów uczelni, wykorzystałem metodę analizy treści ${ }^{7}$. Analiza polegała na tym, że - opierając się na treściach (wartościowaniach, normach, deklaracjach) przypisywanych różnym etosom nauki oraz wstępnym rozeznaniu wypowiedzi (sformułowań) z analizowanych dokumentów — stworzyłem listę cech, zwanych wskaźnikami ${ }^{8}$, które ujawniają to, jakie deklarowane wartości, normy zapisane są w badanych dokumentach. Na liście znalazły się przede wszystkim te wskaźniki, które występują $\mathrm{w}$ analizowanych dokumentach, lecz również te, które powinny się $\mathrm{w}$ nich znaleźć, ponieważ przytaczane są w dyskusjach dotyczących etosu nauki jako powinności. Ostatecznie wyróżniłem 32 wskaźniki, a następnie zestawiłem je w 6 zbiorów o zróżnicowanej liczebności. Są to grupy wskaźników:

- poznawczych (9 wskaźników),

- dyscyplinujących (4 wskaźniki),

- prospołecznych (4 wskaźniki),

- użytkowych (6 wskaźników),

- humanistycznych (7 wskaźników),

— dydaktycznych i wychowawczych (2 wskaźniki).

Określone rodzaje wartości, norm, deklaracji występujących w etosie nauki zostały $\mathrm{w}$ ten sposób zoperacjonalizowane za pomocą wymienionych typów wskaźników. Wskaźniki posłużyły do skonstruowania kwestionariusza, który umożliwiał poszukiwanie w badanych dokumentach odpowiednich sformułowań. Wyniki zestawiłem w postaci tabel, macierzy dwuwskaźnikowych tworzących obraz obecności/nieobecności poszczególnych wskaźników w dokumentach danej uczelni. W kolumnach wymieniłem wskaźniki, a w wierszach — badane dokumenty. Podczas analizy macierzy stworzyłem dwa indeksy: częstotliwości występowania w badanych dokumentach danych wskaźników oraz intensywności występowania danego

${ }^{7}$ E. BabBie: Podstawy badań społecznych. Tłum. W. Betkiewicz [et al.]. Warszawa 2008.

${ }^{8}$ Odwołuję się do pojęcia „wskaźnik” występującego w socjologii, w której oznacza on ilościową miarę służącą do zbadania obecności jakiegoś elementu. Wyróżnianie wskaźników wiąże się z operacjonalizacją, to znaczy przekształceniem abstrakcyjnego pojęcia w coś możliwego do zaobserwowania i zmierzenia. Zob. Słownik socjologii i nauk społecznych. Red. G. Marshall. Red. nauk. pol. wyd. M. Tabin. Warszawa 2005, s. 219, 427; Encyklopedia socjologii. Suplement. Kom. red. Z. BoKsZAŃsKi. Warszawa 2005, s. $386-393$. 
typu wskaźników (wartości, norm, deklaracji) w tych dokumentach. Indeks częstotliwości informuje, jak często wskaźniki danego typu występowały w zbiorze wszystkich wskaźników zaobserwowanych $\mathrm{w}$ badanych dokumentach. Przykładowo, wskaźniki poznawcze w 10 analizowanych dokumentach uczelni badawczych wystąpiły 34 razy, natomiast w tych samych dokumentach wskaźniki humanistyczne - 19 razy. Częstotliwość wskaźników poznawczych była większa niż wskaźników humanistycznych. W ten sposób można zestawić wszystkie typy wskaźników. Czy to oznacza, że w podanym przykładzie znaczenie wskaźników poznawczych jest w badanych dokumentach większe od znaczenia wskaźników humanistycznych? Niekoniecznie. Okazuje się, że niektóre liczne wskaźniki występują w mniejszej liczbie dokumentów, a te nieliczne - w większej liczbie dokumentów. Aby zniwelować te różnice, wprowadziłem drugi indeks intensywności występowania wskaźników. Oto jak skonstruowałem ten indeks: uzyskane dane umieściłem w macierzy, w której jednym wymiarem jest wykaz analizowanych dokumentów, a drugim - lista wskaźników charakteryzujących dany ich typ. Macierz stworzyła pole możliwych do zajęcia miejsc. Przykładowo, jeśli wyróżniłem 9 wskaźników poznawczych i zbadałem 10 dokumentów, to pól możliwych do zajęcia było 90. Indeks intensywności występowania wartości poznawczych dla wszystkich dokumentów wynosiłby $100 \%$, gdyby w każdym z nich były sformułowania dotyczące wszystkich wskaźników poznawczych. Taka sytuacja oznaczałaby, że wartości poznawcze są ważne, ponieważ są powszechnie deklarowane. Tak jednak nie jest, ponieważ tylko w części dokumentów zapisano wartości wchodzące w skład wskaźników poznawczych. W efekcie tylko jakiś odsetek pól macierzy jest zajęty. Ta wielkość, wyrażona w procentach, jest wskazówką informującą o tym, jaką wagę przywiązują uczelnie do wartości tworzących deklarowany etos nauki, informuje o intensywności aprobaty dla danego zestawu wskaźników tworzących deklarowany etos nauki.

Każdy z wymienionych indeksów (częstotliwości występowania oraz intensywności występowania) ma swoje mocne i słabe strony. Indeks częstotliwości występowania jest prosty, „naturalny”. Jego wadą jest to, że w przypadku przewagi liczebnej wskaźników danego typu może sugerować, że mają one większe znaczenie niezależnie od tego, jakie znaczenie mają faktycznie w budowie etosu nauki. Zaletą indeksu intensywności wskaźnika jest to, że indeks ten niweluje ewentualną liczebną przewagę wskaźników danego typu i ukazuje stopień ich obecności. Można to pokazać obrazowo: cóż z tego, że w badanych dokumentach wskaźników poznawczych jest 50, jeśli występują one tylko $\mathrm{w}$ co trzecim dokumencie. Tymczasem tylko 2 wskaźniki tworzące inną normę występują niemal w każdym dokumencie. $\mathrm{Z}$ tych powodów w swoich badaniach wykorzystywałem przede wszystkich 
indeks intensywności występowania wartości i tylko w podsumowaniu korzystam również z indeksu częstotliwości.

\section{Etos nauki}

Nauka podlega licznym przemianom, w tym o charakterze aksjologicznym. Przemiany etosu nauki są przedmiotem zainteresowania wielu badaczy, prezentujących odmienne podejścia ${ }^{9}$. Punktem wyjścia przedstawionych w literaturze przedmiotu sposobów pojmowania etosu nauki jest zazwyczaj propozycja jego rozumienia sformułowana przez Roberta K. Mertona. Jego zdaniem ,[e]tos naukowy to zabarwiony emocjonalnie zespół wartości i norm uważanych za obowiązujące ludzi nauki. Są one wyrażone w postaci nakazów, zakazów, reguł preferencji i dopuszczalności, które są uprawomocnionymi wartościami instytucjonalnymi"'10. Dalej Merton pisze, że owe wartości i normy są w różnym stopniu zinternalizowane przez naukowców, nie są przedmiotem szczególnych opracowań, lecz mogą być wyprowadzone $\mathrm{z}$ „,moralnego konsensu uczonych, który wyrażany jest w praktyce i zwyczajach" "1. Twierdzi, że w nauce występuje zestaw instytucjonalnych nakazów, które konstytuują etos nauki akademickiej; są to: komunizm, uni-

9 Zob. B. Readings: Uniwersytet $w$ ruinie. Przekł. S. Stecko. Warszawa 2017; K. Szadkowski: Uniwersytet jako dobro wspólne. Podstawy krytycznych badań nad szkolnictwem wyższym. Warszawa 2015; S. KRIMSKY: Nauka skorumpowana? O niejasnych zwiazkach nauki i biznesu. Przeł. B. BiaŁy. Warszawa 2006; J. Dudek: Etos uniwersytetu a globalny klopot z jego tożsamościa. „Studies in Global Ethics and Global Education" 2017, no. 7, s. 24-42. http://sgege.aps.edu.pl/ [dostęp: 2.05.2019]; K. GrZESIAK: Etos nauki - między klerkowskim a eksperckim modelem nauki. „Zeszyty Naukowe. Zbliżenia Cywilizacyjne" 2017, T. 13 (4), s. 64-76. https://doi.org/10.21784/ZC.2017.024; J. GoćKowski: Ethos nauki i role uczonych. Kraków 1996; IDEM: Uniwersytet i tradycja w nauce. Kraków 1999; M. KwIEK: Narodziny uniwersytetu z ducha nowoczesności. Uwagi o transformacjach instytucji w epoce globalnej. „Principia. Pisma Koncepcyjne z Filozofii i Socjologii Teoretycznej”, T. 37-38, s. 45-60; A. LeKKA-Kowalik: Uniwersytet jako firma ustugowa - szansa czy klęska? „Ethos” 2009, vol. 85-86 (1-2), s. 52-69; M. Rembierz: Uniwersytet - wolność - bezinteresowność. Tradycyjny etos $i$ współczesne przemiany tożsamości uniwersytetu. „Pedagogika Szkoły Wyższej” 2015, nr 2, s. 11-48. https://doi.org/10.18276/psw.2015.2-01.

${ }^{10}$ R.K. Merton: Teoria socjologiczna i struktura społeczna. Przeł. E. MorawsKa, J. Werenstein-ŻuŁaWski. Wstęp i red. nauk. J.J. Wiatr. Warszawa 1982, s. 580.

${ }^{11}$ Ibidem. 
wersalizm, bezinteresowność, zorganizowany sceptycyzm. Komunizm oznacza, że nauka ma charakter publiczny. Odkrycia naukowe są efektem współpracy i własnością wspólnoty, stanowią jej wspólne dziedzictwo. „Etyka naukowa ogranicza prawa własności w nauce do absolutnego minimum"12 i wiąże się z nakazem wymiany informacji i publikowania badań. Wiedza naukowa poddawana jest kontroli innych naukowców, co zapewnia obiektywizm naukowych osiągnięć. „Komunizmu etosu naukowego nie da się pogodzić z definicją technologii jako »własności prywatnej« w gospodarce kapitalistycznej"13. Z tak rozumianym wspólnotowym charakterem nauki nie idzie w parze pojęcie własności intelektualnej. $\mathrm{Z}$ uniwersalizmem nauki natomiast wiąże się przekonanie, że kryteria prawdziwości twierdzeń nie zależą od indywidualnych postaw badaczy, lecz mają bezosobowy charakter. Ważne są obiektywne kryteria osiągnięć naukowych. Bezinteresowność nauki z kolei oznacza, zdaniem Mertona, aprobatę dla ograniczonego zestawu motywów leżących u podstaw aktywności badawczej. Ten badacz sądzi, że w nauce właściwą motywacją jest satysfakcja $\mathrm{z}$ dokonania odkrycia naukowego, a jednocześnie twierdzi, że bezinteresowność stanowi raczej strukturę kontroli efektów. W tym kontekście pisze: „Zachowania uczonych poddane są [...] swoistej instytucjonalnej kontroli, obejmującej szeroki wachlarz motywów"14. Tak rozumiana bezinteresowność eliminuje osobiste uprzedzenia i buduje obiektywizm oparty na uzgodnieniu. Zasada zorganizowanego sceptycyzmu wydaje się kluczowa wśród norm przedstawionych przez Mertona. Oznacza krytycyzm wobec twierdzeń obecnych w nauce, konieczność zawieszenia sądów do czasu zebrania bezspornych danych.

Polemicznym wobec sformułowanego przez Mertona etosu nauki akademickiej jest etos, czy też model, nauki przemysłowej (postindustrialnej). Etos ten, którego propozycję przedstawił John Ziman ${ }^{15}$, opisuje związki nauki z przedsiębiorstwami, głównie z laboratoriami korporacji. W etosie nauki przemysłowej kluczowe jest dostarczanie rezultatów, które mają bezpośrednią wartość komercyjną. Zasady etosu nauki przemysłowej to: własność, lokalność, autorytaryzm, zlecanie, eksperckość. Nauka jest własnościowa, co oznacza, że wyniki badań są indywidualną własnością, w szczególności tych, którzy zamawiają i finansują badania, a nie jest dobrem wspólnym; oznacza to ograniczenie dostępu do wiedzy. Nauka jest lokalna, czyli nastawiona na wąsko podejmowane badania o charakterze praktycznym. Od

${ }^{12}$ Ibidem, s. $584-585$.

13 Ibidem, s. 586.

14 Ibidem, s. 587.

15 J.M. Ziman: Is Science Losing Its Objectivity? „Nature” 1996, no. 382, s. 751-754. https://oi.org/10.1038/382751a0; IDEM: Real Science: What It Is, and What It Means. Cambridge-New York 2000. 
nauki wedle tego etosu nie oczekuje się tworzenia uogólnień wyjaśniających szersze zjawiska. Nauka przemysłowa zarządzana jest autorytarnie, to znaczy, że nie jest motywowana bezinteresownym dążeniem do prawdy, a działania badaczy są kontrolowane (sprawdza się, w jaki sposób realizują oni cele, zadania sformułowane przez zewnętrzne instytucje). W tak rozumianym modelu badacze odgrywają rolę ekspertów, a ich badania są zamawiane przez różne instytucje.

Pomiędzy opisanymi dwoma modelami etosu nauki sytuowany jest etos nauki postakademickiej. W jego ramach mieszczą się różne mało sprecyzowane propozycje. Próby ilościowego scharakteryzowania etosu nauki postakademickiej zostały przedstawione między innymi przez Marzenę Feldy ${ }^{16}$ oraz Jacka Bielińskiego i Aldonę Tomczyńskąa ${ }^{17}$ Zdaniem Feldy nauka dzisiaj nie spełnia warunków ani modelu Mertonowskiego, ani modelu przemysłowego. W jakimś stopniu nowa, postakademicka nauka realizuje zmienione warunki obu; nie jest bezinteresowna, ale zachowuje obiektywizm; nie jest wspólnotowa, ale opiera się na współpracy. „Zespoły badawcze zaczęły działać niczym małe przedsięwzięcia biznesowe, a ich członkowie stali się konsultantami lub ekspertami, pełniącymi funkcje doradcze i przygotowującymi raporty na zlecenie. Wspólnie pracują nad problemami, których sami nie postawili, i są wynagradzani według swojego wkładu w sukces zespołu"18. Na poparcie tych tez Feldy podaje wyniki badań wyobrażeń 800 naukowców o nauce i sposobach jej funkcjonowania. Wyniki te sugerują, że badacze przyjmują jedną z czterech postaw (po około $20-25 \%$ respondentów w każdej grupie), reprezentujących etosy: nauki akademickiej, nauki przemysłowej, nauki postakademickiej, oraz nieutożsamiających się $\mathrm{z}$ żadnym modelem ${ }^{19}$.

Oprócz wymienionych przeze mnie, jak sądzę najważniejszych dzisiaj, sposobów pojmowania etosu nauki wyróżniane są inne. Janusz Goćkowski²0 pisze o dwóch biegunowo odmiennych modelach nauki: klerkowskim i eksperckim. Model klerkowski utożsamiany jest z naukami humanistycznymi, w których uczeni sytuują się w roli mędrców, moralistów, niezaangażowanych intelektualistów. Natomiast model ekspercki utożsamiany jest $\mathrm{z}$ techniką - naukowcy z tej dziedziny uznawani są za inżynierów konstruujących świat. Marek Kwiek zauważa kryzys dotychczasowego, postoświeceniowego modelu uniwersytetu i widzi nową ideę, ,którą z wielką radością uznaje za swoją część świata anglosaskiego: to idea doskonałości, excellence in

\footnotetext{
${ }^{16}$ M. Feldy: Etos nauki..., s. 67-98.

17 J. BielińsKi, A. TomCZyŃsKa: Etos nauki..., s. 219-250.

18 M. Feldy: Etos nauki..., s. 74.

19 Ibidem, s. 85.

${ }^{20}$ J. GoćKowski: Ethos nauki i role uczonych...
} 
education, za którą stoją ideały wiedzy najbardziej pożytecznej i najlepiej się sprzedającej" 21 . Uniwersytety realizujące ten model nastawione są na zaspokajanie potrzeb studentów-konsumentów, a zarządzane są w sposób biurokratyczny, właściwy korporacjom. Joanna Dudek ${ }^{22}$ przedstawia przywołuje przy tym rozważania Sheldona Krimsky’ego - bardziej złożone modele uprawiania nauki. Wyróżnia model klasyczny, Baconowski, obronny, pro publico bono. Do zadań modelu klasycznego należą nauczanie, prowadzenie badań oraz krytyczna analiza tradycji kultury i cywilizacji. Zadaniem uniwersytetów w modelu Baconowskim jest dostarczanie kadry, wiedzy i technologii służących ekonomicznemu i przemysłowemu rozwojowi społeczeństwa. Uniwersytety obronne funkcjonują w czasach wojny, a uniwersytety pro publico bono dostarczają rozwiązań najważniejszych problemów społecznych.

\section{Analiza obecności etosu nauki w statutach uczelni}

W analizowanych dokumentach poszukiwane cechy etosu nauki przyjmują bardzo zróżnicowany status, mogą występować pod postacią ideałów, norm, ocen. Ideały ujawniają się jako cele i wartości najwyższe. Normy to nakazy (w mniejszym stopniu zakazy) określające właściwy sposób postępowania; najczęściej przyjmują formę deklaracji wskazujących wyróżniony sposób (regułę) postępowania, działania.

Przedstawione uwagi dotyczące aksjologicznych aspektów nauki oraz zaprezentowana dalej analiza normatywnych wątków obecnych w przyjętych po uchwaleniu nowej ustawy o nauce i szkolnictwie wyższym statutach uczelni ukazują dużą złożoność struktury normatywnej nauki.

\footnotetext{
${ }^{21}$ M. KwIEK: Narodziny uniwersytetu..., s. 56.

22 J. Dudek: Etos uniwersytetu..., s. 24-42.
} 


\section{Wskaźniki tworzące wartości poznawcze}

Deklaracje, sformułowania odwołujące się do wartości poznawczych obecne w statutach uczelni są zróżnicowane. Można wyodrębnić 9 wskaźników charakteryzujących wartości poznawcze:

1) dążenie do prawdy;

2) poszerzanie rozumienia świata;

3) podkreślanie znaczenia naukowych kryteriów wiarygodnej wiedzy;

4) krytycyzm wobec powszechnie uznawanych sądów;

5) uznanie, że odkrycia naukowe są własnością całej wspólnoty akademickiej;

6) uznanie, że zadaniem uczelni jest prowadzenie badań;

7) uznanie, że zadaniem uczelni jest krytyczna analiza tradycji kultury i cywilizacji;

8) pochwała wolności badań naukowych, działalności artystycznej i kształcenia;

9) aprobata dla wolności debaty.

Wskaźniki te są charakterystyczne dla etosu nauki akademickiej.

Wśród wartości poznawczych w statutach uczelni badawczych najczęściej występują sformułowania dotyczące wolności badań naukowych, działalności artystycznej i kształcenia oraz te, które wskazują, że zadaniem uczelni jest prowadzenie badań. Przynajmniej jeden ze wskaźników wartości poznawczych jest odnotowany w 8 na 10 dokumentów. Natomiast, co zaskakujące, $\mathrm{w}$ ogóle nie ma sformułowań związanych $\mathrm{z}$ jednym $\mathrm{z}$ podstawowych elementów etosu nauki akademickiej - mianowicie z tym, że wartością jest krytycyzm wobec powszechnie uznawanych sądów.

Wartości poznawcze najczęściej występują w statutach Uniwersytetu im. Adama Mickiewicza oraz Akademii Górniczo-Hutniczej w Krakowie; w dokumentach tych występuje 5 z 9 wskaźników wartości poznawczych. Natomiast w każdym analizowanym dokumencie występują co najmniej 2 wskaźniki wartości poznawczych. Najmniej deklaracji (po 2) dotyczących wartości poznawczych znajduje się w statutach Uniwersytetu Mikołaja Kopernika oraz Gdańskiego Uniwersytetu Medycznego. W analizowanych statutach uczelni badawczych wskaźniki tworzące wartości poznawcze występują 34 razy na 90 możliwych wystąpień (10 analizowanych dokumentów i 9 wskaźników wartości poznawczych) — indeks intensywności występowania wartości poznawczych wynosi więc 37,7\%. Także w analizowanych dokumentach (statutach i jednej strategii rozwoju) uczelni $\mathrm{z}$ terenu Górnośląsko-Zagłębiowskiej Metropolii najczęściej występuje deklaracja (3 deklaracje na 5 dokumentów) dotycząca prowadzenia badań oraz wolno- 
ści badań naukowych, działalności artystycznej i kształcenia. W dokumentach uczelni Metropolii, tak jak w dokumentach uczelni badawczych, nie ma żadnej deklaracji dotyczącej krytycyzmu wobec powszechnie uznawanych sądów.

$\mathrm{Na}$ terenie GZM najczęściej deklaracje dotyczące wartości poznawczych występują w statutach Uniwersytetu Śląskiego w Katowicach oraz Śląskiego Uniwersytetu Medycznego w Katowicach — po 4 deklaracje na 9 wskaźników; deklaracje te są nieco rzadsze niż w statutach uczelni badawczych. W analizowanych dokumentach uczelni Metropolii wskaźniki tworzące wartości poznawcze występują 14 razy - indeks intensywności wartości poznawczych wynosi $29,16 \%$ (wskaźniki tworzące wartości poznawcze etosu nauki w uczelniach Metropolii zajmują 14 pól na 45 możliwych - 5 analizowanych dokumentów i 9 wskaźników).

\section{Wskaźniki tworzące normy dyscyplinujące}

Sformułowania, które przywołują normy dyscyplinujące, także są zróżnicowane, choć znacznie mniej niż te dotyczące wartości poznawczych. W analizowanych dokumentach można wyróżnić 4 wskaźniki charakteryzujące normy dyscyplinujące:

1) podkreślanie znaczenia kontroli;

2) podkreślanie znaczenia oceniania;

3) podkreślanie znaczenia odpowiedzialności;

4) sprzeciw wobec konfliktu interesów.

Wskaźniki te można zaliczyć do etosu nauki przemysłowej.

W dokumentach uczelni badawczych wśród norm dyscyplinujących najczęściej można zaobserwować znaczenie oceniania. Wskaźnik ten występuje w 5 analizowanych dokumentach na 10. Najrzadziej, tylko raz, odnotowano deklarację zwrócenia uwagi na konflikt interesów. Wskaźniki charakteryzujące normy dyscyplinujące najczęściej (2 na 4 możliwe) występują w statutach Politechniki Gdańskiej, Akademii Górniczo-Hutniczej w Krakowie oraz Uniwersytetu Wrocławskiego, natomiast wcale - w statutach Uniwersytetu Jagiellońskiego oraz Gdańskiego Uniwersytetu Medycznego. W analizowanych dokumentach uczelni badawczych wskaźniki tworzące normy dyscyplinujące występują 11 razy, więc indeks intensywności występowania norm dyscyplinujących wynosi $27,5 \%$, a to oznacza, że wskaźniki tworzące normy dyscyplinujące etosu nauki w uczelniach badawczych zajmują 11 pól na 40 możliwych (10 analizowanych dokumentów i 4 wskaźniki). 
W dokumentach uczelni Metropolii najczęściej deklarowane jest znaczenie kontroli (przywołane zostało 3 razy w 5 dokumentach). Pozostałe wskaźniki albo deklarowane są jednorazowo, albo wcale. Najczęściej normy dyscyplinujące występują w statucie Uniwersytetu Śląskiego (2 razy na 4 wskaźniki), w dokumentach pozostałych uczelni obecne są pojedyncze przywołania albo nie ma ich $\mathrm{w}$ ogóle. W analizowanych dokumentach uczelni Metropolii wskaźniki tworzące normy dyscyplinujące występują łącznie 4 razy - wskaźniki tworzące normy dyscyplinujące etosu nauki w uczelniach Metropolii zajmują 4 pola na 20 możliwych (5 analizowanych dokumentów i 4 wskaźniki), co oznacza, że indeks intensywności występowania norm dyscyplinujących wynosi $20 \%$.

\section{Wskaźniki tworzące deklaracje prospołeczne}

Sformułowania, w których obecne są wartości prospołeczne, są podobnie zróżnicowane jak te odnoszące się do norm dyscyplinujących. W badanych dokumentach można wyróżnić 4 wskaźniki deklaracji prospołecznych:

1) uznawanie, że zadaniem uczelni jest dostarczanie kadry;

2) uznawanie, że zadaniem uczelni jest dostarczanie wiedzy i technologii

służących ekonomicznemu i przemysłowemu rozwojowi społeczeństwa;

3) uznawanie, że zadaniem uczelni jest rozwiązywanie najważniejszych problemów społecznych (walka z chorobami, biedą, zanieczyszczaniem środowiska naturalnego);

4) uznawanie, że zadaniem uczelni jest współpraca $z$ otoczeniem.

Połowa wskaźników ma źródło w modelu Baconowskim etosu, a jedna reguła odwołuje się do etosu uniwersytetu pro publico bono.

Wśród wskaźników prospołecznych najczęściej deklarowane są uznawanie dostarczania kadry oraz współpracy z otoczeniem za zadanie uczelni (7 wskazań na 10 dokumentów uczelni badawczych). Natomiast w połowie analizowanych statutów zapisano po 3 z 4 wskaźników prospołecznych. $\mathrm{W}$ analizowanych dokumentach uczelni badawczych wskaźniki tworzące normy dyscyplinujące występują 22 razy. Indeks intensywności występowania norm prospołecznych wynosi 55\% — wskaźniki tworzące deklaracje prospołeczne etosu nauki w uczelniach badawczych zajmują 22 pola na 40 możliwych (10 analizowanych dokumentów i 4 wskaźniki).

Wśród deklaracji prospołecznych aż w 4 na 5 analizowanych dokumentów uczelni Metropolii występują deklaracje dotyczące postrzegania współpracy z otoczeniem jako zadania uczelni, niewiele mniej wskazań (3) dotyczy 
zadania dostarczania kadry. Pozostałe wskaźniki zostały przywołane jednokrotnie. Wszystkie wskaźniki prospołeczne znalazły się w strategii rozwoju Uniwersytetu Śląskiego, a żaden wskaźnik tego typu nie został zapisany w statucie tej szkoły wyższej. W badanych dokumentach uczelni GZM wskaźniki tworzące normy dyscyplinujące występują 9 razy. Natomiast indeks intensywności występowania norm dyscyplinujących wynosi $45 \%$ — wskaźniki tworzące deklaracje prospołeczne etosu nauki w uczelniach Metropolii zajmują 9 pól na 20 możliwych (5 analizowanych dokumentów i 4 wskaźniki).

\section{Wskaźniki tworzące normy użytkowe}

Wartości użytkowe widoczne są w takich deklaracjach, które odwołują się do postulatów komercjalizacji formułowanych w etosie nauki przemysłowej. W badanych dokumentach można znaleźć 6 tego typu wskaźników podkreślających znaczenie:

1) umiędzynarodowienia działalności uczelni;

2) widzialności uczelni;

3) własności intelektualnej;

4) komercjalizacji wyników badań;

5) rozwiązywania problemów praktycznych;

6) specjalizacji badań.

W połowie analizowanych dokumentów uczelni badawczych wśród wartości użytkowych zapisana została aprobata dla komercjalizacji wyników badań, nieco rzadziej (3 razy na 10 dokumentów) deklarowane jest znaczenie umiędzynarodowienia. Pozostałe wskaźniki użytkowe nie występują. Najczęściej wskaźniki tworzące wartości użytkowe są przywoływane w statucie Uniwersytetu Mikołaja Kopernika (3 razy na 6 wskaźników). Żadne tego typu wskaźniki nie zostały zapisane w statutach 3 uczelni badawczych: Uniwersytetu Warszawskiego, Uniwersytetu Jagiellońskiego, Gdańskiego Uniwersytetu Medycznego. W analizowanych dokumentach uczelni badawczych wskaźniki tworzące normy użytkowe odnotowano 14 razy. Indeks intensywności występowania wskaźników dyscyplinujących wynosi 23,33\% normy użytkowe etosu nauki w uczelniach badawczych zajmują 14 pól na 60 możliwych (10 analizowanych dokumentów i 6 wskaźników).

W dokumentach uczelni Metropolii najczęściej (2 razy na 5 dokumentów) spośród wartości użytkowych deklarowane są normy dotyczące umiędzynarodowienia oraz własności intelektualnej. Pozostałe wskaźniki wybie- 
rane są pojedynczo. Deklaracje dotyczące wartości użytkowych najczęściej (4 deklaracje na 6 wskaźników) występują w strategii rozwoju Uniwersytetu Śląskiego. Natomiast w ogóle nie są wymieniane w statutach Śląskiego Uniwersytetu Medycznego w Katowicach oraz Uniwersytetu Ekonomicznego w Katowicach. W analizowanych dokumentach uczelni Metropolii wskaźniki tworzące normy użytkowe odnotowano 8 razy. Indeks intensywności występowania norm dyscyplinujących wynosi $26,66 \%$ — wskaźniki tworzące normy użytkowe etosu nauki w uczelniach Metropolii zajmują 8 pól na 30 możliwych (5 analizowanych dokumentów i 6 wskaźników).

\section{Wskaźniki tworzące wartości humanistyczne}

Normy humanistyczne nie zostały przywołane wprost w przedstawionych wcześniej koncepcjach etosu nauki. W badanych dokumentach można wyróżnić 7 wskaźników odzwierciedlających różne wartości humanistyczne:

1) poszanowanie ludzkiej godności;

2) sprzeciw wobec wszelkiej dyskryminacji;

3) równość szans wszystkich członków wspólnoty uczelni;

4) idee tolerancji, praw człowieka, demokracji;

5) poparcie dla idei współudziału członków wspólnoty uczelni w podejmowaniu decyzji;

6) znaczenie funkcji rzecznika praw i wartości;

7) znaczenie funkcji rzecznika praw studenta i doktoranta.

Spośród wartości humanistycznych w statutach uczelni badawczych najczęściej (6 deklaracji w 10 dokumentach) deklarowana jest aprobata dla idei humanizmu, tolerancji, praw człowieka, demokracji, odpowiedzialności, wspólnoty ludzkiej. Najrzadziej występuje deklaracja o konieczności powołania rzecznika praw studenta i doktoranta. Deklaracje dotyczące wartości humanistycznych najczęściej (5 razy na 7 wskaźników) były przywoływane w statucie Uniwersytetu Jagiellońskiego, a w ogóle ich nie ma w statucie Gdańskiego Uniwersytetu Medycznego. W analizowanych dokumentach uczelni badawczych wskaźniki tworzące wartości humanistyczne pojawiły się 19 razy. Indeks intensywności występowania wartości humanistycznych wynosi $27,14 \%$ - wskaźniki tworzące wartości humanistyczne etosu nauki w uczelniach badawczych zajmują 19 pól na 70 możliwych (10 analizowanych dokumentów i 7 wskaźników).

W analizowanych dokumentach uczelni GZM prawie wszystkie wskaźniki przywoływane są jednokrotnie (z wyjątkiem wskaźnika: udział w po- 
dejmowaniu decyzji, który nie występuje w żadnym dokumencie). Do tego prawie wszystkie (częstotliwość: 6 razy na 8 wskaźników) zapisano w statucie Uniwersytetu Śląskiego. W analizowanych dokumentach uczelni Metropolii siedmiokrotnie odnotowano wskaźniki tworzące wartości humanistyczne. Indeks intensywności występowania wartości humanistycznych wynosi $20 \%$ — wskaźniki tworzące wartości humanistyczne etosu nauki w uczelniach Metropolii zajmują 7 pól na 35 możliwych (5 analizowanych dokumentów i 7 wskaźników).

\section{Wskaźniki tworzące deklaracje dotyczące zadań dydaktycznych i wychowawczych uczelni}

$\mathrm{W}$ analizowanych dokumentach zestaw norm wynikających $\mathrm{z}$ deklaracji dotyczących zadań dydaktycznych i wychowawczych uczelni jest mało zróżnicowany; chodzi o deklaracje, które uznają nauczanie i zadania wychowawcze za składniki decydujące o istocie uczelni, a nie odnoszące się tylko aspektów technicznych, organizacyjnych związanych ze studiowaniem. W badanych dokumentach można wyróżnić 2 wskaźniki powiązane z zadaniami dydaktycznymi i wychowawczymi szkoły wyższej:

1) zadaniem jest nauczanie;

2) uczelnia ma zadania wychowawcze.

Deklaracje dotyczące dydaktyki i wychowania zapisane zostały w większości analizowanych dokumentów uczelni badawczych. Nie występują tylko w statucie Politechniki Warszawskiej. W analizowanych dokumentach uczelni badawczych trzynastokrotnie przywołane zostały wskaźniki tworzące deklaracje dydaktyczne i wychowawcze. Natomiast indeks intensywności występowania norm dotyczących dydaktyki i wychowania wynosi $65 \%$ wskaźniki tworzące te deklaracje w uczelniach badawczych zajmują 13 pól na 20 możliwych (10 analizowanych dokumentów i 2 wskaźniki).

Deklaracje dotyczące dydaktyki i wychowania zapisano w większości analizowanych dokumentów uczelni Metropolii, oprócz statutu Uniwersytetu Ekonomicznego w Katowicach. W dokumentach tych wskaźniki tworzące deklaracje dydaktyczne i wychowawcze występują 7 razy. Indeks intensywności występowania norm z zakresu dydaktyki i wychowania wynosi $70 \%$ - wskaźniki tworzące te deklaracje w uczelniach Metropolii zajmują 7 pól na 10 możliwych (5 analizowanych dokumentów i 2 wskaźniki). 


\section{Wnioski}

W nowych statutach uczelni badawczych oraz szkół wyższych zlokalizowanych na terenie Górnośląsko-Zagłębiowskiej Metropolii paleta deklarowanych wartości i norm budujących etos nauki jest zróżnicowana i bogata. Liczne elementy koncepcji opisanych w literaturze dotyczącej etosu nauki można wyodrębnić w zrekonstruowanym etosie, lecz nie można go do nich zredukować. Zasadniczymi składnikami zrekonstruowanego etosu są wartości: poznawcze, prospołeczne, humanistyczne, użytkowe, dyscyplinujące, dotyczące zadań uczelni w zakresie dydaktyki i wychowania. Wartości te zostały zapisane $\mathrm{w}$ badanych dokumentach zarówno uczelni badawczych, jak i szkół wyższych z terenu Metropolii, pojawiają się jednak z różną częstotliwością i intensywnością.

Częstotliwość występowania wskaźników tworzących wymienione wartości przedstawiono $\mathrm{w}$ tabeli 1 . W analizowanych dokumentach uczelni badawczych poszukiwane wskaźniki przywołano 113 razy, natomiast w dokumentach szkół wyższych Metropolii — 49 razy.

Tabela 1

Częstotliwość występowania wskaźników etosu nauki

w statutach uczelni badawczych oraz statutach i strategii rozwoju szkół wyższych

Górnośląsko-Zagłębiowskiej Metropolii — porównanie (dane liczbowe i procentowe)

\begin{tabular}{|l|c|c|c|c|}
\hline \multirow{2}{*}{\multicolumn{1}{|c|}{ Nazwa grupy wskaźników }} & \multicolumn{2}{c|}{$\begin{array}{c}\text { Statuty uczelni } \\
\text { badawczych }\end{array}$} & \multicolumn{2}{c|}{$\begin{array}{c}\text { Statuty oraz strategia } \\
\text { rozwoju uczelni } \\
\text { Metropolii }\end{array}$} \\
\cline { 2 - 5 } & $N$ & procent & $N$ & procent \\
\hline Wartości poznawcze & 34 & 30,08 & 14 & 28,57 \\
\hline Deklaracje prospołeczne & 22 & 19,46 & 9 & 18,36 \\
\hline Wartości humanistyczne & 19 & 16,81 & 7 & 14,28 \\
\hline Normy użytkowe & 14 & 12,38 & 8 & 16,32 \\
\hline $\begin{array}{l}\text { Deklaracje dotyczące dydaktyki } \\
\text { i wychowania jako zadań uczelni }\end{array}$ & 13 & 11,50 & 7 & 14,28 \\
\hline Normy dyscyplinujące & 11 & 9,73 & 4 & 8,16 \\
\hline \multicolumn{1}{|c|}{ R a z e m } & 113 & $99,96^{*}$ & 49 & $99,97^{*}$ \\
\hline
\end{tabular}

* Dane nie sumują się do 100\%, ponieważ wartości były zaokrąglane do setnej liczby po przecinku. Źródło: badania własne.

W obu grupach uczelni deklarowana hierarchia tworzących etos nauki wartości jest podobna pod względem częstotliwości ich występowania. Na 
czele są wskaźniki tworzące wartości poznawcze, następnie prospołeczne, na końcu zaś deklaracje dotyczące dyscyplinowania. Małe różnice widoczne są w hierarchii i proporcji uznawania wartości humanistycznych, norm użytkowych oraz deklaracji dotyczących dydaktyki i wychowania jako zadań uczelni — po deklaracjach prospołecznych w uczelniach badawczych znalazły się wartości humanistyczne, normy użytkowe oraz deklaracje dotyczące dydaktyki i wychowania, natomiast w uczelniach Metropolii - normy użytkowe, następnie humanistyczne oraz (z taką samą liczbą wskaźników) deklaracje dotyczące dydaktyki i wychowania jako zadań uczelni.

W obu grupach uczelni hierarchia liczebności wskaźników opisujących poszczególne typy wartości tworzących etos nauki jest podobna, zaobserwować można jednak duże różnice w zakresie indeksu intensywności występowania wskaźników (tabela 2).

Tabela 2

Intensywność występowania wskaźników etosu nauki w statutach uczelni badawczych oraz w statutach i strategii rozwoju szkół wyższych Górnośląsko-Zagłębiowskiej Metropolii — porównanie (dane procentowe)

\begin{tabular}{|l|c|c|}
\hline \multicolumn{1}{|c|}{ Nazwa grupy wskaźników } & $\begin{array}{c}\text { Statuty uczelni } \\
\text { badawczych } \\
{[\%]}\end{array}$ & $\begin{array}{c}\text { Statuty } \\
\text { i strategia rozwoju } \\
\text { uczelni Metropolii } \\
{[\%]}\end{array}$ \\
\hline $\begin{array}{l}\text { Deklaracje dotyczące dydaktyki i wychowania } \\
\text { jako zadań uczelni }\end{array}$ & 65,00 & 70,00 \\
\hline Deklaracje prospołeczne & 55,00 & 45,00 \\
\hline Wartości poznawcze & 37,70 & 29,16 \\
\hline Normy dyscyplinujące & 27,50 & 20,00 \\
\hline Wartości humanistyczne & 23,75 & 17,50 \\
\hline Normy użytkowe & 23,33 & 26,60 \\
\hline
\end{tabular}

Źródło: badania własne.

Porównanie tabel 1 i 2 ujawnia zaskakującą sytuację. Indeks intensywności, który informuje, jaki odsetek potencjalnych wyborów w obrębie danej grupy wskaźników jest faktycznie obecny w badanych dokumentach, pokazuje, że wskaźniki tworzące deklaracje dotyczące dydaktyki i wychowania jako zadań uczelni występują w większości analizowanych dokumentów, a wskaźniki tworzące normy użytkowe - w około jednej czwartej. Najliczniejsze (zob. tabela 1) w badanych dokumentach wskaźniki wartości poznawczych zapisano tylko w jednej trzeciej statutów, co oznacza, że w statutach, w których się znalazły, są liczne, a w pozostałych ich nie ma. Natomiast wskaźniki o najmniejszej częstotliwości, opisujące normy dyscyplinujące, znaleziono w jednej czwartej analizowanych dokumentów. 
Przy czym intensywność większości uwzględnianych wartości jest nieco większa w dokumentach uczelni badawczych niż w dokumentach szkół wyższych z GZM. Z kolei intensywność, także niezbyt licznych, wskaźnikach deklaracji dotyczących dydaktyki i wychowania jako zadań uczelni jest największa. Wskaźniki te można wyodrębnić niemal we wszystkich badanych dokumentach. Taka dysproporcja między indeksami częstotliwości i intensywności występowania wskaźników wartości tworzących etos nauki sugeruje, że uczelnie przywiązują odmienną wagę do różnych wartości. Część licznych wskaźników znaleźć można w nielicznych dokumentach, a inne - mniej liczne - (niemal) we wszystkich.

Czy, a jeśli tak, to w jakim stopniu etos nauki odzwierciedlony w uchwalonych przez uczelnie po przyjęciu nowej ustawy o nauce i szkolnictwie wyższym dokumentach różni się od wcześniejszego? Porównanie tych etosów jest w jakimś stopniu możliwe dzięki mojej opublikowanej w 2018 roku w czasopiśmie „Analecta” analizie ${ }^{23}$. We wnioskach sformułowanych w artykule sprzed trzech lat sformułowana jest teza, że w dokumentach uczelni Metropolii przyjętych przed wejściem w życie nowej ustawy o szkolnictwie wyższym dominowały wskaźniki należące do etosu nauki akademickiej (niniejsza analiza pokazuje, że obecnie dominują raczej wskaźniki wartości poznawczych) oraz — w mniejszym stopniu — przemysłowej (dziś w dużym stopniu wskaźniki norm użytkowych i dyscyplinowania). Można więc stwierdzić, że przyjęcie nowej ustawy nie doprowadziło do znaczącego przesunięcia treści etosu nauki $\mathrm{z}$ wartości poznawczych na rzecz norm użytkowych i dyscyplinujących. Natomiast w etosie pojawiły się, wcześniej nie uwzględnione, inne wartości i normy. Wbrew wielu wypowiedziom głoszącym tezę o wzrastającej roli etosu przemysłowego w nauce (oznaczającego przechodzenie od priorytetu wartości poznawczych do utylitarnych i znaczenia dyscyplinowania w zarządzaniu) trudno w analizowanych dokumentach znaleźć potwierdzenie dużej intensywności tego procesu. Wejście w życie nowej ustawy o szkolnictwie wyższym nie wpłynęło znacząco na zmianę etosu nauki deklarowanego przez grupę badaczy decydujących w senatach o przyjęciu nowych dokumentów. Warto kolejny raz podkreślić, że mowa o deklarowanych wartościach. Pobieżny przegląd innych, nie tak fundamentalnych jak te analizowane, dokumentów uczelni może sugerować ich inne priorytety. To jednak wymaga systematycznego badania.

Odpowiedź na pytania i hipotezy sformułowane we wstępie może być następująca: etos nauki obecny $\mathrm{w}$ analizowanych dokumentach obu grup uczelni jest rozbudowany i zróżnicowany. Trzeba jednak podkreślić, że wyróżnione wskaźniki występują $\mathrm{w}$ dokumentach badanych uczelni z bardzo

${ }^{23}$ T. CzAKon: Etos nauki naukowców a etos nauki w kodeksach etycznych wyższych uczelni... 
odmienną częstotliwością i intensywnością. W statutach niektórych uczelni deklaracje konstruujące etos nauki są wyraźnie obecne, a w niektórych niemal wcale (tabela 3).

Tabela 3

Ranking uczelni według liczby wskaźników wartości etosu nauki w analizowanych dokumentach (statutach i strategii)

\begin{tabular}{|l|c|}
\hline \multicolumn{1}{|c|}{ Uczelnia } & $\begin{array}{c}\text { Liczba } \\
\text { wskaźników* }\end{array}$ \\
\hline Politechnika Gdańska & 16 \\
\hline Uniwersytet Śląski w Katowicach (statut) & 16 \\
\hline $\begin{array}{l}\text { Akademia Górniczo-Hutnicza im. Stanisława } \\
\text { Staszica w Krakowie }\end{array}$ & 15 \\
\hline Uniwersytet im. Adama Mickiewicza & 15 \\
\hline Uniwersytet Śląski w Katowicach (strategia) & 13 \\
\hline Uniwersytet Wrocławski & 12 \\
\hline Uniwersytet Jagielloński & 11 \\
\hline Uniwersytet Mikołaja Kopernika & 11 \\
\hline Politechnika Śląska w Gliwicach & 10 \\
\hline Uniwersytet Warszawski & 9 \\
\hline Śląski Uniwersytet Medyczny w Katowicach & 8 \\
\hline Politechnika Warszawska & 7 \\
\hline Gdański Uniwersytet Medyczny & 5 \\
\hline Uniwersytet Ekonomiczny w Katowicach & 1 \\
\hline * Lączna liczba wszystkich wskaźników wartości etosu nauki to 32. \\
Źr ódło: badania własne.
\end{tabular}

Tabela ilustruje bardzo duże zróżnicowanie liczebności wskaźników tworzących etos nauki w analizowanych dokumentach wybranych uczelni wyższych. Dla części senatów prace nad statutami były okazją do przypomnienia deklaracji ideowych dotyczących nauki, a dla części statuty są tylko dokumentem regulującym sprawy organizacyjne. Odpowiedź na pytania dotyczące częstotliwości i intensywności występowania w statutach wartości i norm definiujących etos nauki nie jest więc jednoznaczna. $Z$ jednej strony zestaw wartości jest zróżnicowany, odzwierciedla przemiany nauki. $Z$ drugiej strony jednak problem etosu nauki okazał się ważny tylko dla części uczelni. Świadczą o tym dane zebrane w tabelach - znaczna część wartości występuje w statutach w ograniczonym zakresie, a w części statutów prawie w ogóle. 
Chociaż analizowane dokumenty ujawniają, jak rozbudowana i zróżnicowana jest paleta wartości i że trudno sprowadzić je do jakiegoś typu etosu dyskutowanego w literaturze przedmiotu, to można przyznać, że zrekonstruowany etos ma charakter postakademicki - wychodzi poza kanon etosu naukowego sformułowany przez Roberta K. Mertona.

\section{Bibliografia}

BabBie E.: Podstawy badań społecznych. Tłum. W. BetKiewicz [et al.]. Warszawa 2008.

Bieliński J., TomczyŃsKa A.: Etos nauki we wspótczesnej Polsce. „Nauka i Szkolnictwo Wyższe" 2019, $\mathrm{nr} \quad 1-2$ (53-54), s. 219-250. https://doi.org/10.14746//nisw.2019.1-2.7.

CZAKON T.: Etos nauki naukowców a etos nauki w kodeksach etycznych wyższych uczelni. „Analecta. Studia i Materiały z Dziejów Nauki” 2018, R. 27, z. 2 (53), s. $99-113$.

DUdeK J.: Etos uniwersytetu a globalny klopot z jego tożsamościa. „Studies in Global Ethics and Global Education" 2017, no. 7, s. 24-42. http://sgege.aps.edu.pl/ [dostęp: 2.05.2019].

Encyklopedia socjologii. Suplement. Kom. red. Z. BoksZaŃski. Warszawa 2005.

FELDY M.: Etos nauki a podejście do promocji nauki. „MINIB. Marketing Instytucji Naukowych i Badawczych" 2018, $\mathrm{nr} 2$ (28), s. 67-98. https://doi.org/10.14611/minib.28.06.2018.04.

GoćKOwsKi J.: Ethos nauki i role uczonych. Kraków 1996.

GoćKowsKi J.: Uniwersytet i tradycja w nauce. Kraków 1999.

GRZESIAK K.: Etos nauki - między klerkowskim a eksperckim modelem nauki. „Zeszyty Naukowe. Zbliżenia Cywilizacyjne” 2017, T. 13 (4), s. 64-76. https://doi.org/10.21784/ZC.2017.024.

KRIMSKY S.: Nauka skorumpowana? O niejasnych zwiazkach nauki i biznesu. Przeł. B. Biaty. Warszawa 2006.

KwIEK M.: Narodziny uniwersytetu z ducha nowoczesności. Uwagi o transformacjach instytucji w epoce globalnej. „Principia. Pisma Koncepcyjne z Filozofii i Socjologii Teoretycznej" 2004, T. 37-38, s. 45-60.

LeKKA-KowaliK A.: Uniwersytet jako firma ustugowa - szansa czy klęska? „Ethos” 2009, vol. 85-86 (1-2), s. 52-69.

[Lista uczelni wyłonionych w pierwszym konkursie programu Ministra Nauki i Szkolnictwa Wyższego „Inicjatywa doskonałości — uczelnia badawcza”]. http://www.bip.nauka.gov.pl/g2/oryginal/2019_10/6ce53b5cae3f256eb8095549c7f a71c4.pdf [dostęp: 18.04.2020]. 
Merton R.K.: Teoria socjologiczna i struktura społeczna. Przeł. E. MorawskA, J. Werenstein-ŻulaWski. Wstęp i red. nauk. J.J. Wiatr. Warszawa 1982.

Readings B.: Uniwersytet $w$ ruinie. Przekł. S. Stecko. Warszawa 2017.

REMBIERz M.: Uniwersytet - wolność - bezinteresowność. Tradycyjny etos i współczesne przemiany tożsamości uniwersytetu. „Pedagogika Szkoły Wyższej” 2015, nr 2, s. 11—48. https://doi.org/10.18276/psw.2015.2-01.

Stownik socjologii i nauk społecznych. Red. G. MARSHALL. Red. nauk. pol. wyd. M. TABIN. Warszawa 2005.

SzadKowski K.: Uniwersytet jako dobro wspólne. Podstawy krytycznych badań nad szkolnictwem wyższym. Warszawa 2015.

Ustawa z dnia 20 lipca 2018 r. - Prawo o szkolnictwie wyższym i nauce. „Dziennik Ustaw” 2018, poz. 1668.

Ziman J.M.: Is Science Losing Its Objectivity? „Nature” 1996, no. 382, s. 751-754. https://doi.org/10.1038/382751a0.

Ziman J.M.: Real Science: What It Is, and What It Means. Cambridge-New York 2000 . 